\title{
Hear no Evil, See no Evil: Why Antitrust Compliance Programmes may be Ineffective at Preventing Cartels
}

by

\author{
Andreas Stephan \\ ESRC Centre for Competition Policy \& Norwich Law School, \\ University of East Anglia
}

\section{CCP Working Paper 09-09}

\begin{abstract}
Cartel practices attract enormous corporate fines, even where they only involve a handful of employees. Internal compliance programmes are thought to protect firms by training employees and auditing their activities. However, this paper argues that such programmes are ineffective because cartelists typically know what they are doing is illegal, go to great lengths to avoid detection and are usually senior managers. Moreover, compliance programmes do not mitigate cartel fines, despite their being imposed on the whole corporation years after an infringement has occurred. It is argued that the threat of criminal sanctions against individuals is essential to effective internal compliance.
\end{abstract}

July 2009

JEL Classification Codes: K14, K21, L40, L41

Keywords: Competition Law; Antitrust Compliance; Cartels; Article 81

\section{Acknowledgements:}

The support of the Economic and Social Research Council is gratefully acknowledged.

\section{Contact details:}

Andreas Stephan, ESRC Centre for Competition Policy, University of East Anglia, Norwich, NR4 7TJ, UK.

a.stephan@uea.ac.uk 


\section{Introduction}

Cartels are considered the most serious breaches of competition law described by the US Supreme Court as the "supreme evil of antitrust" ${ }^{1}$ - and so attract by far the greatest penalties in terms of pecuniary fines. Since 2000, the European Commission alone has imposed fines totalling nearly $€ 12$ billion (\$16.5 b) on 316 undertakings involved in horizontal breaches of Article 81 EC. The only protection for firms is that fines cannot exceed 10 per cent of annual worldwide turnover in all operations, ${ }^{2}$ meaning that fines can be proportionately greater where the infringement involved a subsidiary or a small part of an undertaking's operations. It is thought that the threat of corporate fines of this magnitude provides a strong incentive for firms to 'keep their ship in order' by maintaining effective internal compliance efforts. These competition law compliance programmes ostensibly protect firms; in particular by reducing the scope for future infringements through training, and uncovering potential current infringements through the periodic auditing of company activities. However, colluding with a competitor need involve little more than an exchange of emails or the odd telephone call, motivated by the irresistible promise of higher profits through less competition. Mechanisms created to ensure the objectives of the firm and its employees are aligned (such as profit linked bonus schemes) only serve to fuel this temptation.

This paper argues that internal compliance programmes are ineffective at preventing cartel behaviour in the absence of criminal sanctions against individuals. Empirical evidence from infringements uncovered in the recent past shows how those responsible for cartels typically know what they are doing is illegal, go to great lengths to avoid detection, and are usually senior managers within the firm. Moreover, compliance programmes do not mitigate cartel fines in the US and the EU, despite their being imposed on the whole corporation, years after the infringement actually occurred. It is argued that compliance programmes serve an important educational role, but will only succeed in preventing serious infringements where cartel behaviour carries direct consequences for the individual. In the absence of this, compliance programmes may simply highlight the fact that the corporation as a whole bears the risk of breaches of competition law by individual employees.

\section{Why Firms should be Worried about Cartel Breaches by their Employees}

Practices such as price fixing, output restriction and market sharing continue to attract unprecedented levels of fines from the European Commission, the US Department of Justice (DOJ), and increasingly from national competition authorities within the Community, such as the UK's Office of Fair Trading (OFT). In 2008, the European Commission imposed €2.27 billion on just 34 undertakings, with a further 4 receiving immunity from fines in return for uncovering the infringement. In the Car Glass cartel case, the French glass producer Saint-Gobain was fined a staggering €896 million for its involvement

\footnotetext{
${ }^{1}$ Verizon Communications, Inc. v. Law Offices of Curtis V. Trinko, 124 S. Ct. (2004) at 879.

${ }^{2}$ Article 23, Council Regulation (EC) No 1/2003 of 16 December 2002. OJ [2003] L 001.
} 
in the infringement. Typically, this fine was imposed more than a decade after the anticompetitive behaviour was first instigated and some nine years after the infringement ceased. ${ }^{3}$ By this time, many of the individuals involved may have left the firm and the burden of these enormous fines will have been felt by current employees and shareholders; the majority of whom may not have benefited from the illegal profits accrued during the period of collusion. Fines of this magnitude can also attract adverse publicity and loss of reputation, especially where a firm sells to final consumers rather than operating upstream. Heavy sanctions can be justified on three grounds: (i) they reflect the seriousness of the conduct punished in distorting competition; (ii) they enhance the efficiency of leniency programmes by making the difference between the immunity prize (available to the first firm only) and the consequences for firms who fail to cooperate sufficiently stark to induce selfreporting. This helps to increase the number of cartel cases that come to light; (iii) they aim to achieve an effective level of deterrence in the face of unknown numbers of cartel infringements going undetected.

However, what makes cartel infringements particularly worrying for corporations is the ease with which breaches can be committed by a relatively small number of employees. Article $81 \mathrm{EC}$, for example, does not require a formal agreement between competitors to be in place; all that is required is that information be directed to a competitor, who accepts it with a view to coordinating action between them. ${ }^{4}$ In the era of emails, mobile phones and instant messaging, the reckless exchange of information between an employee and their counterpart at a competitor is all too easy. ${ }^{5}$ This has been outlined in a number of recent UK cases such as Hasbro and Sevenoaks Survey where emails were used to exchange information. ${ }^{6}$ The Passenger Fuel Surcharges case, in which British Airways was fined $£ 121.5$ million by the OFT and $\$ 300$ million by the DOJ in 2007, largely concerned a handful of telephone conversations between British Airways sales executives and their counterparts at Virgin Atlantic. ${ }^{7}$ It does not matter that competitors were only discussing a small part of the final price (the fuel surcharge in the above case) or whether the conduct actually had an effect on prices. ${ }^{8}$ Moreover, the fact that an employee has chosen to coordinate the cartel from home does not make it less likely that fines will be imposed on the firm. Under Article 21 of Regulation 1/2003, the Commission has the power to inspect 'any other premises... including the homes of directors, managers and other members of staff of the undertakings and associations of undertakings concerned' where 'a reasonable suspicion exists that books or other records related to the

\footnotetext{
${ }^{3}$ DG Competition Press Release, 'Antitrust: Commission fines car glass producers over $€ 1.3$ billion for market sharing cartel' (12 November 2008) IP/08/1685.

${ }^{4}$ ICI v Commission ('Dyestuffs') [1972] CMLR 55; Suiker Unie v Commission [1976] 1 CMLR 295.

${ }^{5}$ DC Klawiter and JM Driscoll, 'Antitrust compliance in the age of multi-jurisdictional leniency: new ideas and new challenges' (2009) GCR Supp (The Antitrust Review of the Americas).

${ }^{6}$ Agreements between Hasbro UK Ltd and distributors fixing the price of Hasbro toys and games CA98/18/2002 at 92; Exchange of information on future fees by certain independent

fee-paying schools CA98/05/2006 at 347. Emails were also used in the European case French Beef to maintain agreed price scales: COMP/F-3/38.279 French Beef OJ [2003] L 209/12 at 52-53.

7 OFT Press Release, 'British Airways to pay record $£ 121.5 \mathrm{~m}$ penalty in price fixing investigation' (1 August 2007) 113/07; 'BA price-fixing inquiry: phone conversations under scrutiny' (23 June 2006) The Guardian, London.

${ }^{8}$ Cimenteries CBR SA v Commission [2000] 5 CMLR 204 at 1849.
} 
business and to the subject-matter of the inspection, which may be relevant to prove a serious violation of Article $81 \ldots$ are being kept in [those premises]'. ${ }^{9}$

The danger to firms is intensified by the use of leniency programmes by competition authorities. These provide immunity to the first firm to self-report an infringement, leaving the other companies involved exposed to the steep pecuniary fines outlined above. The stark difference between the immunity prize and the consequences of being beaten in the race to the competition authority make it more important than ever that firms are able to effectively detect and deter breaches of cartel laws within their organisations.

\section{The Model Competition Law Compliance Programme}

It is difficult to determine the extent to which corporations have adopted competition law compliance programmes, and the amount of time and money that is invested into compliance efforts. In the US, where antitrust enforcement is generally considered to be more rigorous than any other jurisdiction, compliance programmes appear commonplace. The American Bar Association (ABA) Antitrust Compliance: Perspectives and Resources for Corporate Counselors provides a comprehensive compliance sourcebook and a snapshot of the typical competition law compliance programme adopted by firms in the US and recommended by US competition lawyers. It includes extracts from compliance manuals provided by firms including: General Motors, Hewlett-Packard, Coca-Cola and Michelin.

Compliance manuals provide a statement of policy and ethical conduct expected and endorsed by the firm. All employees whose activities raise antitrust issues will normally be made to read its contents, attend training seminars and sign that they have completed this training. ${ }^{10}$ Training is accompanied with regular monitoring and periodic audits to test the compliance programme's effectiveness. Many compliance manuals give a list of 'DOs' and 'DON'Ts' to avoid breaches out of ignorance. These will include never discussing prices or some component of prices with competitors (e.g. discount, surcharge, transportation charge, etc), and never discussing the process of setting prices (such as bids for tender). In relation to market allocation, employees should never talk to competitors about where the company intends to sell products, which products they will sell, and which customers they will sell to. There are of course entirely legitimate and lawful reasons why competitors might communicate with each other. Trade Associations can play an important role in a number of areas such as standard setting and promoting innovation. Compliance manuals deal with such interactions by stressing the importance that employees avoid language which could be interpreted as inviting competitors to take certain action, such as "prices are too low at the moment". ${ }^{11}$ Above all, compliance manuals and

\footnotetext{
${ }^{9}$ For a discussion see: WPJ Wils, Efficiency and Justice in European Antitrust Enforcement (Oxford: Hart 2008) pp.3-6.

${ }^{10}$ ABA Section of Antitrust Law, Antitrust Compliance: Perspectives and Resources for Corporate Counselors' (ABA Publishing, Chicago 2005) pp.64-69.

${ }^{11}$ ABA, Antitrust Compliance (n 10) p.68.
} 
training educate employees about what antitrust laws are and the consequences of breaching them.

The Antitrust Audit is thought to play a key role in ensuring compliance. Coupled with the compliance manual and training, it signals to employees that the corporation is serious about complying with competition law. ${ }^{12}$ It also gives the firm an edge in applying for immunity or leniency, by providing a mechanism through which possible infringements may be uncovered early. ${ }^{13}$ Audits are best undertaken by external legal counsel who are insulated from the prevailing corporate culture within specific divisions of the firm. ${ }^{14}$ External counsel also have the advantage of enjoying legal privilege in Europe, whereas in-house competition lawyers generally do not. ${ }^{15}$ In the US and Canada, privilege applies to in house lawyers unless they are acting as company officers rather than advisers. ${ }^{16}$ Audits might include unannounced inspections of retained documents, emails and telephone records, and will focus on parts of the firm which have pricing, output and sales responsibilities. ${ }^{17}$ Kolasky identifies a number of red flags that antitrust audits should pay particular attention to: trade association activity; sales transactions between the corporation in question and its competitors (especially at regular intervals); market shares that are more stable than one would expect; phone calls from individuals giving fictitious names or refusing to identify themselves; sudden unexpected price increases; and copies of competitor price announcements in the company's files. ${ }^{18}$

Finally, the support of senior management is considered fundamental if compliance efforts are to be meaningful and effective. ${ }^{19}$ Their support is important, both in terms of ensuring sufficient resources and company time is dedicated to compliance, and that any breaches of company policy on competition law are dealt with effectively. Their backing also encourages a culture of compliance in which employees exclude anticompetitive conduct from their possible courses of action in improving the performance of the firm. ${ }^{20}$

\footnotetext{
${ }^{12}$ M Furse and S Nash The Cartel Offence (Oxford: Hart 2004) p120-5; ABA, Antitrust Compliance (n 10) p.121.

${ }_{13}$ ABA, Antitrust Compliance (n 10) pp.114-20.

${ }^{14}$ Furse and Nash (n 12) p.121.

${ }^{15}$ Case 155/1979, AM\&S Europe Limited v Commission [1982] ECR 1575; see Wils (n 9) at paras 48-60

$16 \mathrm{~J}$ Joshua, 'Antitrust compliance programmes for multinational companies' (2001) International Financial Law Review Supp (Competition and Antitrust 2001).

${ }_{17}$ ABA, Antitrust Compliance (n 10) p.122.

18 WJ Kolasky (US Department of Justice), 'Antitrust Compliance Programs: The Government Perspective' Speech given to Corporate Compliance 2002 Conference, Practicing Law Institute, 12 July 2002, San Francisco.

${ }^{19}$ OFT, 'How your business can achieve compliance' (n 51) at 10; K S Desai, 'Antitrust compliance programmes' (2006) GCR Nov Supp (The European Antitrust Review) pp.15-21; Joshua (n 16); ABA, Antitrust Compliance (n 10), p.81.

${ }^{20}$ See: C Parker, 'The 'compliance' trap: the moral message in responsive regulatory enforcement' (2006) Law \& Society Review, 40(3), pp.591-622.
} 


\section{Why Compliance Programmes are Ineffective at Preventing Cartels}

The three key characteristics of an effective compliance programme outlined above are: training, auditing and the support of senior management. Turning to what we know empirically from infringements uncovered in the last fifteen years, there are a number of factors which suggest competition law compliance programmes may be ineffective at preventing cartels or protecting firms from high fines. For one thing, there is little doubt that the employees responsible generally know what they are doing is illegal, but choose to do it anyway in the pursuit of collusive profits. This is epitomised by the Lysine cartel meetings secretly filmed by the FBI in the 1990s, in which senior executives ridiculed both competition authorities and their customers, and the ominous phrase "our customers are our enemies" was employed. ${ }^{21}$ Knowledge of illegality is also evidenced by emails used in the Hasbro and Sevenoaks Survey cases in the UK. These were signed off with "...never put anything in writing, it's highly illegal and it could bite you in the arse!!!!" and "Confidential please, so we aren't accused of being a cartel."22 In Graphite Electrodes, the cartel members even continued the collusive agreement after the European Commission had launched its investigation, succeeding in sustaining the infringement until a year later. ${ }^{23}$ Tempted by the promise of cartel profits and undeterred by the possibility of high fines being imposed on the whole corporation years later, these individuals' behaviour is unlikely to be changed by compliance training alone. Indeed, in Arriva and FirstGroup the participants of a market sharing agreement acted in clear disregard of very recent internal compliance training which had been implemented to meet the requirements of the UK's (then new) Competition Act 1998. ${ }^{24}$

The cartels uncovered and punished in the last 20 years also show that: (i) cartelists go to great lengths to disguise their collusive activities and avoid detection by competition authorities and compliance audits; (ii) most cartels are coordinated by individuals holding senior managerial positions, making it difficult for firms to deal with such breaches of competition laws internally; and (iii) compliance efforts provide no mitigation of fines in the US and EU, even where an effective compliance programme is in place.

\subsection{Lengths to which Individuals go to Avoid Detection}

The most successful cartels (in terms of maximising illegal profits) hold regular meetings. This is especially so in industries with more than four producers, where tacit collusion (without direct contact/agreement) is less likely. Meetings will be necessary in order to agree on the action that will be collectively taken, deal with demand and cost shocks, and monitor whether every party is

\footnotetext{
${ }^{21}$ James Randall, then President of Archer Daniels Midland. 'Videotapes Take Star Role at Archer Daniels Trial' (4 August 1998) The New York Times, New York; JM Connor, 'Our Customers are Our Enemies: The Lysine Cartel of 1992-1995' (2001) Review of Industrial Organisation 18, pp.5-21.

${ }^{22}$ Agreements between Hasbro UK Ltd, Argos Ltd and Littlewoods Ltd fixing the price of Hasbro toys and games CA98/2/2003 [2003] UKCLR 553, para. 53; M Furse Competition Law of the EC and the UK (OUP Oxford 2006) p.112; Sevenoaks Survey (n 6); 'Top public schools found guilty of fee-fixing cartel' (23 October 2005) The Times, London.

${ }^{23}$ C-308/94 SGL Carbon AG v. Commission [2006] ECR I-05977at 64.

${ }^{24}$ Market sharing by Arriva plc and FirstGroup plc CA98/9/2002 at 18-19 \& 27; see also M Furse and S Nash The Cartel Offence (Oxford: Hart 2004) p.119.
} 
adhering to the agreement. Many of the cartels uncovered in recent years went to great lengths to hold such meetings while avoiding detection or the creation of evidence. These efforts are likely to have become even more sophisticated and elaborate with the escalation of competition law enforcement in Europe and the US. Efforts to conceal cartels include: staggered price announcements or bids to give the impression of genuine competition; communicating through private email accounts and unregistered mobile phones using encrypted messages; avoiding any contact through secretaries or other administrative staff; avoiding the use of documents at meetings or destroying them immediately afterwards; claiming cash to pay for expenses associated with cartel meetings or hiding them as other expenses. ${ }^{25}$ In Graphite Electrodes, a complex system of code names was devised to cover the real identities of the companies and their complicit executives. SGL was referred to as 'BMW', UCAR as 'Pinot', the Japanese producers as 'Chivas', 'Ocean', 'Lawn' and 'Dry' - 'COLD' for short. VAW Carbon was known as 'Wave'. Individuals were given names including 'Artemis', 'Moustache' and 'Taurus'. In Carbonless Paper, the Commission noted how:

Virtually all documentary traces of the activities of the cartel were suppressed: almost no minutes, records, lists of participants or invitations survived. In these circumstances it is not possible to declare with absolute certainty that all the participants have put an end to the infringement. ${ }^{26}$

Vitamins and Citric Acid are other examples where evidence had been so successfully suppressed that the Commission could not be entirely sure the infringement had ended. ${ }^{27}$

Favoured locations for meetings include hotel rooms ${ }^{28}$ (especially airport hotels), private conference rooms ${ }^{29}$ and even restaurants. ${ }^{30}$ Locations for meetings of international cartels vary between continents, but there seems to be a particularly high propensity among cartels prosecuted by the EC for meetings in Switzerland. ${ }^{31}$ However, Trade Associations have also been commonly employed as a lawful cover for cartel meetings. They allow competitors to legitimately travel to the same location and either undertake anti-competitive exchanges among perfectly legitimate industry discussions, or hide them in the social activities that typically accompany Trade Association meetings. The Lysine cartel, for example, created a working group within the Fédération Européene des Fabricants d'Adjuvants pour la Nutrition Animale (Fefana), using a fake Fefana agenda to cover regular cartel

\footnotetext{
${ }^{25}$ See in particular: COMP/38.889 Gas Insulated Switchgear OJ [2008] C 266/1 at 10; COMP/E1/36.490 Graphite Electrodes OJ [2002] L 100/1 at 59; COMP/E-1/37.027 Zinc Phosphate OJ [2003] L $153 / 1$ at 253.

${ }^{26}$ COMP/E-1/36.212 Carbonless Paper OJ [2004] L 115/1 at 368.

${ }^{27}$ COMP/E-1/37.512 Vitamins OJ [2003] L 006/1 at 653; COMP/E-1/36.604 Citric Acid OJ [2002] L 239/18 at 195.

${ }^{28}$ Carbonless Paper (n 26) at 123; COMP/C/37.519 Methionine OJ [2003] L 255/1 at 162; COMP/F3/37.614 Interbrew and Alken-Maes OJ [2003] L 200/1 at 5; Amino Acids (n 32) at 81; Zinc Phosphate (n 25) at 102.

${ }^{29}$ COMP/F/38.638 BR / ESBR OJ [2008] C 007/11 at 11.

30 COMP/C/37.671 Food Flavour Enhancers OJ [2005] L 075/1 at 143; COMP/E-2 /37.978 Methylglucamine OJ [2004] L 038/18 at 65; 9; COMP/E-3/36.700 Industrial and Medical Gases OJ [2003] L 084/1 at 104.

${ }^{31}$ Examples include: COMP/E-2/37.857 Organic Peroxide OJ [2005] L 110/44 at 72; COMP/E-1/37.512 Vitamins OJ [2003] L 006/1 at 499; Citric Acid (n 27) at 78; Graphite Electrodes (n 25) at 46.
} 
meetings. ${ }^{32}$ The Electrical and Mechanical Carbon and Graphite cartel held its meetings in the margins of the European Carbon and Graphite Association. ${ }^{33}$ The Citric Acid cartel also used a Trade Association as a cover, for all cartel members were also members of the European Citric Acid Manufacturers Association (ECAMA). Meetings were typically held in private on the evening before the ECAMA meetings. ${ }^{34}$

These efforts make it very difficult for an antirust audit to uncover collusive behaviour, even where firms undertake the significant cost of ensuring executives are accompanied to Trade Association events by a competition lawyer or internal compliance officer. Indeed, Kolasky recalls an instance where an executive was accompanied to a meeting with a foreign competitor to discuss the exchange of technical information. The executive in question staged the meeting with his counterparts as if it was the first time they had met, with the customary exchange of business cards and pleasantries - all to the satisfaction of those overseeing his meeting. It later transpired the executive in question had been socialising, playing golf and fixing prices with this individual for years. ${ }^{35}$

\subsection{Level at which Decision is Made}

As cartels involve restricting output, raising prices and sharing markets, it perhaps comes as no surprise that they are typically coordinated at a senior level of a corporation or its subsidiary. These are after all, the individuals 'whose employment is dependent on corporate (or business unit) profitability'. ${ }^{36}$ Table 1 below lists 40 international cartels prosecuted in Europe and/or the US since 1998, in which the positions of employees involved were named in decisions of the European Commission or in Press Releases of the US Department of Justice.

Table 1: International Cartels 1998-2008

\begin{tabular}{|c|c|c|}
\hline YEAR & CARTEL & POSITION(S) OF EMPLOYEES INVOLVED \\
\hline 2009 & LCD SCREENS*† & $\begin{array}{l}\text { President of Subsidiary; Executive Vice President of Sales } \\
\text { and Marketing; Vice President of Sales Planning. }\end{array}$ \\
\hline 2008 & AIR CARGO† & $\begin{array}{l}\text { Director of Sales and Marketing; Commercial General } \\
\text { Manager }\end{array}$ \\
\hline $2007-8$ & MARINE HOSES*† & $\begin{array}{l}\text { President; Product Area Manager; Managing Director; } \\
\text { Director, Sales and Marketing; Regional Sales Manager. }\end{array}$ \\
\hline 2007 & $\begin{array}{l}\text { PASSENGER FUEL } \\
\text { SURCHARGE (BA/VIRGIN) }\end{array}$ & $\begin{array}{l}\text { Head of Sales; Commercial Director; Head of } \\
\text { Communications }\end{array}$ \\
\hline 2007 & DUTCH BEER* & Managing Directors \\
\hline 2007 & LIFTS \& ESCALATORS & National Sales Managers \\
\hline $2004-7$ & DRAM† & Vice President, Sales \& Marketing; Head of Global Sales \\
\hline 2006 & $\begin{array}{l}\text { ACRYLIC GLASS } \\
\text { (METHACRYLATES) }\end{array}$ & Regional Sales Managers; Senior Management \\
\hline
\end{tabular}




\begin{tabular}{|c|c|c|}
\hline 2006 & HYDROGEN PEROXIDE & $\begin{array}{l}\text { Heads of Department; General manager; CEO; Marketing } \\
\text { managers. }\end{array}$ \\
\hline 2005 & RUBBER CHEMICAL*† & Accounts Managers; Sales Managers \\
\hline 2005 & INDUSTRIAL BAGS & Accounts Managers \\
\hline 2005 & ITALIAN RAW TOBACCO* & Purchasing managers; Chairmen \\
\hline 2005 & INDUSTRIAL THREAD & General Managers; Export and Regional managers \\
\hline 2005 & MCAA CHEMICALS† & $\begin{array}{l}\text { Product Managers; Sales Managers; Marketing } \\
\text { managers. }\end{array}$ \\
\hline 2004 & SPANISH RAW TOBACCO* & Chairmen; Local Purchasing Managers \\
\hline 2003 & TANKER SHIPPING $†$ & Vice President; CEO; Co-Managing Director \\
\hline 2003 & $\begin{array}{l}\text { INDUSTRIAL COPPER } \\
\text { TUBES* }\end{array}$ & Vice President; Senior Management \\
\hline 2003 & SORBATES $†$ & Executive Salesmen \\
\hline 2002 & FOOD FLAVOUR & President; General Managers \\
\hline 2002 & SPECIALITY GRAPHITES & $\begin{array}{l}\text { Top level management; Regional management; National } \\
\text { management }\end{array}$ \\
\hline 2002 & AUCTION HOUSES† & Chairmen \\
\hline 2002 & $\begin{array}{l}\text { DUTCH INDUSTRIAL } \\
\text { GASES* }\end{array}$ & CEOs; General managers \\
\hline 2002 & $\begin{array}{l}\text { ANIMAL FEED } \\
\text { METHIONINE* }\end{array}$ & President; CEO; General Manager \\
\hline 2002 & LOMBARD CLUB* & Regional Managers; Chief Executives \\
\hline 2001 & CARBONLESS PAPER & $\begin{array}{l}\text { Chief Executives; Commercial Directors; Regional Sales } \\
\text { Managers }\end{array}$ \\
\hline 2001 & ZINC PHOPSHATE & $\begin{array}{l}\text { Managing Directors; General Managers; Sales Managers; } \\
\text { Marketing Managers }\end{array}$ \\
\hline 2001 & GERMAN BANKS & Senior Executives \\
\hline 2001 & CITRIC ACID* & $\begin{array}{l}\text { Vice President; President of Divisions; Heads of } \\
\text { Marketing; General Managers }\end{array}$ \\
\hline 2001 & $\begin{array}{l}\text { INTERBREW \& ALKEN- } \\
\text { MAES* }\end{array}$ & General Managers \\
\hline 2001 & LUXEMBOURG BREWERS* & General Managers \\
\hline 2001 & VITAMINS*† & $\begin{array}{l}\text { President of Divisions; Division Managers; Marketing } \\
\text { Directors }\end{array}$ \\
\hline 2001 & SODIUM GLUCONATE & $\begin{array}{l}\text { Vice President; General Mangers; Sales Managers; } \\
\text { Marketing Managers. }\end{array}$ \\
\hline 2001 & GRAPHITE ELECTRODES*† & $\begin{array}{l}\text { President; Chairman; Senior Vice President; General } \\
\text { Managers; Local Sales Managers }\end{array}$ \\
\hline 2001 & SAS/MAERSK AIR & Project Managers \\
\hline 2000 & LYSINE (AMINO ACIDS) *† & Executive Vice President; Group Vice President \\
\hline 1999 & SEAMLESS STEEL TUBES & Marketing Managers; Presidents \\
\hline 1998 & ALLOY SURCHARGE & Sales Managers \\
\hline 1998 & GREEK FERRIES & Senior Executives \\
\hline 1998 & PRE-INSULATED PIPES & Directors; Sales Managers; General Managers \\
\hline 1998 & BRITISH SUGAR & Retail Sales Managers \\
\hline
\end{tabular}

As one would expect, there is a strong presence of sales and marketing managers, and some involvement of regional or local management. Sales 
teams or working groups often play an important role in executing the collusive agreement, but most cartels originate at a more senior level. ${ }^{37}$ The majority of cartels are organised by heads of business units and subsidiaries, with a surprising number of cases also involving top level management of the wider corporation, including: Chief Executive Officers, Managing Directors and General Managers. In a number of cases these executives were personally involved in running the cartel; in others they allowed the collusion to occur.

Whether a cartel is instigated by top level management or those heading business units and subsidiaries, the problem is that the support of these individuals is considered important to the effectiveness of a compliance programme. In order to avoid detection, they may either underfund compliance efforts altogether, or create a façade of compliance without any serious mechanisms for detecting or preventing cartel behaviour. Senior executives of F. Hoffmann-La Roche, for example, continued to engage in the Vitamins conspiracy even while they were pleading guilty and paying a fine for their involvement in Citric Acid. A US Department of Justice Official noted,

\begin{abstract}
Incredibly, some senior executives of this multinational firm knew about the firm's participation in international cartels in two industries. When the firm's illegal activities were uncovered in one industry, and the firm had to plead guilty and pay millions of dollars in fines, those executives could have and should have terminated the firm's cartel activities in the second (and larger) industry. Instead, those executives orchestrated false statements to enforcement authorities, took steps to further conceal the firm's illegal activities, and continued to lead the world's other vitamin producers in a global cartel - actions which will end up costing the firm billions of dollars in fines and damages. ${ }^{38}$
\end{abstract}

The involvement of senior executives also makes it less likely that employees (secretaries, administrative assistants, etc) with knowledge of a cartel will come forward and report their employers. ${ }^{39}$ It is interesting that the OFT has followed the South Korean innovation of providing a reward to individual employees who approach them with information. ${ }^{40}$ No rewards have been granted to date.

As it is the shareholders who ultimately suffer the consequences of antitrust fines, they may choose to pursue derivative actions against the senior managers responsible, on behalf of the firm. ${ }^{41}$ However, there are a number of reasons why such actions are unlikely. First, there is little evidence of antitrust audits successfully uncovering secretive hardcore cartels. Knowledge of the infringement will normally surface years after it was instigated and even ceased, meaning that many of the managers responsible may have moved on or retired. Secondly, shareholders may have little incentive to pursue

\footnotetext{
${ }^{37}$ Klawiter and Driscoll (n 5) at 24.

${ }^{38}$ GR Spratling (US Department of Justice), 'International Cartels: the Intersection between FCPA violations and Antitrust violations' Speech at American Conference Institute 9 December 1999, Washington, D.C.

${ }^{39}$ Although the ABA feel that internal whistle blowing can play an effective role: see (n 10) p.31 and p.55.

40 See OFT, 'Rewards for information about cartels' (February 2008) available: http://www.oft.gov.uk/advice and resources/resource base/cartels/rewards

${ }^{41}$ Available in the UK under ss. 260-269 Companies Act 2006; central issues discussed by: F Wagnervon Papp, 'Suing the Suits: Derivative Shareholder Actions to bring home the Message of Antitrust' Speaking at UCL/IMEDIPA Santorini Workshop, 28 May 2009.
} 
derivative actions. Directors and Officers liability insurance does not cover intentional breaches of duty by management, meaning that the funds which might be recovered will be relatively minimal. Moreover, markets are always likely to react negatively to derivative actions, motivating shareholders to simply draw a line under the infringement without taking any action internally.

A further obstacle to firms effectively dealing with those responsible for cartels is weak business attitudes to such practices. This is illustrated by the ease with which those convicted of antitrust offences in the US find re-employment following prison. ${ }^{42}$ In the passenger fuel surcharges case, British Airways admitted it had breached competition rules and despite paying hundreds of millions of pounds in fines and damages, it retained the employment of one of the executives involved and even promoted him at a time when he was pending trial for the UK cartel offence. ${ }^{43}$ The alleged conduct in question fell short of a conventional hardcore cartel; BA executives made a handful of phone calls to their counterparts at Virgin to talk about fuel surcharges. Nevertheless, it is difficult to imagine a senior executive being rewarded with such a promotion, while pending trial for any other white collar crime. Unlike fraud or insider trading, price fixing and market sharing is (in the short run at least) in the interest of the firm, and has historically been accepted as a normal business practice in many industries.

\subsection{Compliance Programmes do not Mitigate Cartel Fines}

As well as concerns that compliance programmes may be ineffective at preventing and detecting cartels, they provide no protection for the firm in terms of mitigating fines, even where disciplinary action has been taken against the individual employees involved. Although the United States Sentencing Guidelines do ostensibly provide mitigation where a firm has had an effective compliance programme in place, this has not been available since November 2004 where 'high-level personnel' participated in the infringement. ${ }^{44}$ These are defined to include anyone within the undertaking with price-setting authority, and so will preclude all hardcore cartel cases. ${ }^{45}$

On the European Community level, the Commission clearly has the discretion to grant downward adjustments in fines to firms that have an effective

\footnotetext{
${ }^{42}$ A Stephan, 'The UK Cartel Offence: Lame Duck or Black Mamba?' (2008) CCP Working Paper 08-19 at 30 .

43 'BA sales chief on price-fixing charge to join the board' (28 November 2008) Financial Times, London; One of the other executives pending trial became a marketing executive for private health provider Bupa - 'The most senior executive involved in the British Airways price-fixing scandal has landed a job at Bupa' (02 December 2008) Evening Standard, London; see also: Robert Wiseman Dairies, 2008 Annual Report, in which bosses were awarded major bonuses despite the firm incurring a $£ 6.1$ million the previous year after admitting price fixing.

${ }_{44}$ United States Sentencing Commission Guidelines Manual (USSG), September 2008. § 8C2.5 (a). 2008 edition available: http://www.ussc.gov/2008guid/GL2008.pdf (accessed 20 April 2009); ABA, Antitrust Compliance ( $\mathrm{n}$ 10) p.20. Under the United States Sentencing Guidelines, fines in antitrust cases are calculated using a base fine set prescribed for a particular offence and a culpability score based on the infringing firm's characteristics. These are then subject to a multiplier which is meant to ensure deterrence § 8C2.6. Under United States v Brooker 125 [US] S. Ct. 738 (2005), judges can depart from the Guidelines, but there has been little evidence of them exercising this right; see SC Hammond, 'Antitrust Sentencing in the Post-Booker Era: Risks Remain High for Non-Cooperating Defendants' Speech at ABA Section of Antitrust Law, Spring Meeting. March 30 2005, Washington, D.C.

${ }^{45}$ See USSG § 8C2.5 Commentary at 514 and ABA, Antitrust Compliance (n 10) p.22.
} 
compliance programme in place, but have chosen not to. ${ }^{46}$ The Courts of Justice have so far refused to interfere with the Commission's discretion in this area, in Cartonboard rejecting arguments that the existence of a compliance programme meant there was no need for the deterrent element of the fine to be imposed. ${ }^{47}$ In Electrical Carbon and Graphite, the Commission stated they "[consider] that it is not appropriate to take the existence of a compliance programme into account as an attenuating circumstance for a cartel infringement, whether committed before or after the introduction of such a programme'. ${ }^{48}$ They have been equally unsympathetic where the firm took actions to discipline the executives involved:

... with regard to the measures adopted by the applicant in order to prevent a repeated infringement on its part (the dismissal of its senior executive officers involved in the offending conduct and the adoption of internal programmes to ensure compliance with the competition rules and awareness raising initiatives for the staff in that connection), it should be noted that, whilst it is indeed important that an undertaking takes steps to prevent fresh infringements of Community competition law from being committed by members of its staff in the future, that circumstance cannot affect the fact that an infringement was found to have been committed. ${ }^{49}$

In the UK, the OFT granted a 10 per cent discount in both Arriva and FirstGroup and Hasbro UK Ltd because the parties had 'genuine compliance systems in place', despite the involvement of senior management in the infringement. ${ }^{50}$ However, in their 2005 guidance on business compliance, the OFT appears to have followed the US example of excluding mitigation where senior management are involved in the infringement:

\begin{abstract}
...the fact that a compliance programme is in place may be taken into account as a mitigating factor when we calculate the level of a financial penalty. We will give careful consideration to the precise circumstances of the infringement and in particular the efforts made by management to ensure that the programme has been properly implemented. We will also take account of the seniority of the person or persons involved in the infringement. We will view very seriously the involvement of directors or senior management in any infringement and may treat such involvement as an aggravating factor when setting the level of financial penalty. For example, the mitigation in having a compliance programme in place may be offset where it was blatantly ignored at a very senior level. ${ }^{51}$
\end{abstract}

The change in US fining policy in 2004 was strongly criticised by the American Bar Association as weakening the incentive for firms to adopt compliance programmes. $^{52}$ This may be particularly so given the difficulties of detecting the kind of infringements that attract significant fines, and the fact that

\footnotetext{
46 'Commission notice on immunity from fines and reduction of fines in cartel cases' OJ [2006] C 298/17

${ }^{47}$ Case T-354/94 Stora Kopparbergs Bergslags AB v. Commission [1998] ECR II-2111 at 115; For discussion see: PM Spink, 'Recent Guidance on Fining Policy' (1999) ECLR 20(2), pp.101-108.

${ }^{48}$ Electrical and mechanical carbon and graphite products $(\mathrm{n} 33)$ at 313 ; see also: COMP/E-1/38.069 Copper Plumbing Tubes OJ L 192/21 at 754; Case T-7/89 Hercules Chemicals v Commission [1991] ECR II-1711 at 357; Case T-31/99 ABB Asea Brown Boveri v Commission [2002] ECR II-1884 at 221; Case T-224/00 Archer Daniels Midland v Commission [2003] ECR II-2597 at 280; see also: Joined cases C-189/02 P, C-202/02 P, C-205/02 P to C-208/02 P and C-213/02 Dansk Rørindustri A/S and others v. Commission [2005] ECR I-05425 at 371-2; Amino Acids (n 32) at 312.

${ }^{49}$ Case T-53/03 BPB v Commission [2008] ECR at 423.

${ }^{50}$ Arriva and First Group (n 24) at 66; Hasbro UK Ltd (n 6) at 92.

${ }^{51}$ OFT, 'How your business can achieve compliance' (2005) OFT 424; see also OFT, 'Enforcement' (December 2004) OFT 407.

${ }^{52}$ ABA, Antitrust Compliance (n 10) p.25-27.
} 
effective compliance requires a substantial investment of resources and employee time by corporations. Firms may question the cost of implementing and maintaining a compliance programme that will only provide limited protection from less serious bilateral breaches of competition law. Others argue that the threat of heavy fines alone should provide sufficient incentive for firms to take compliance seriously, and that infringing firms should rightly not be rewarded for failed compliance. ${ }^{53}$ Empirical work is needed to determine the proliferation of competition law compliance programmes within the business community and the resources and time invested in such activities. $^{54}$

\section{Criminalisation as the Key to Effective Compliance}

The preceding sections have outlined how competition law compliance programmes may be ineffective at detecting and preventing hardcore cartels, because such infringements are typically deliberate, meticulously concealed and organised at a senior level. Training and education is important to hardening attitudes towards cartel practices in the long run, and creating a culture of compliance within the business community. ${ }^{55}$ The ABA warns that ignorance of competition law should not be underestimated; an employee may read a compliance document and understand that price fixing is illegal, but not realise that coordination of surcharges or discounts can amount to the same thing. ${ }^{56}$ The fact that the executives involved in Marine Hoses chose to hold a cartel meeting in the United States on 30 April 2007, certainly demonstrates ignorance or great stupidity, given the well-publicised enforcement and powers of surveillance employed in US antitrust investigations (most famously in the Lysine case).

Training can also promote deterrence by informing employees of the consequences of breaching cartel laws. The difficulty is that most jurisdictions (the European Community level included) only impose sanctions on the wider corporation and not on the individual. The threat of enormous corporate fines and damages in the distant future will do little to dissuade determined cartelists. Indeed, compliance training may only serve to outline how low the stakes are for the individual decision makers; particularly if the number of cartels uncovered and the number of legal jurisdictions with rigorous enforcement are perceived as low. This will be especially so if such practices have been commonplace within the industry in the past. There is thus a need

\footnotetext{
${ }^{53}$ Wils (n 9) at para. 220.

${ }^{54}$ Some empirical research into compliance programmes post-infringement has been undertaken, see: BJ Rodger, 'A Study of Compliance Post-OFT Infringement Action' European Competition Journal (1999) 4:1, p.65; also see: Europe Economics, 'Etat des lieux et perspectives des programmes de conformité' (In French with Executive Summary in English) A report prepared for the Competition Council of France (Conseil de la concurrence) September 2008. Available: http://www.autoritedelaconcurrence.fr/doc/etudecompliance oct08.pdf

${ }^{55}$ See for example: PM Taylor, EC and UK Competition Law and Compliance (London: Sweet \& Maxwell 1999) p.281; we know that public attitudes are relatively week, especially in relation to the appropriate sanctions for individual cartelists: A Stephan, 'Survey of Public Attitudes to Price-Fixing and Cartel Enforcement' (2009) 5(1) CompLRev pp.123-145.

${ }^{56}$ ABA, Antitrust Compliance (n 10) p.32.
} 
to ensure that the stakes at least appear to go against individual cartelists, if any level of effective compliance is to be achieved.

Criminalisation and leniency provide a key incentive for individuals to report collusive practices and desist from indulging in such behaviour in the future. The threat of imprisonment and the availability of immunity to the first individual only (or the employees of the first firm to come forward) ensures that cartelists bear the risk of their illegal practices and sparks a race to the competition authority (usually through their employer) between individual employees keen to avoid incarceration. The principle is exactly the same as in civil procedures against corporations. In the US, the mixture of corporate fines and individual prison sentences - coupled with effective corporate and individual leniency programmes - has been very successful in detecting and deterring cartels. The US Department of Justice secured the conviction of 19 individuals in the fiscal year ending 30 September 2006 alone. In that year, fines on individuals totalled $\$ 473$ million and prison sentences served totalled over five years. ${ }^{57}$ There has already been some evidence of infringements avoiding the US because of the custodial sentences regularly secured there by the Department of Justice. ${ }^{58}$

The problem is that very few jurisdictions outside the US currently have criminal offences that are regularly invoked. In Europe, criminal sanctions cannot be imposed on the Community Level and it is notable that much of the European Commission's apparent success in fining international cartels has actually come about on the back of the DOJ's success. ${ }^{59}$ Moreover, leniency applications in Europe are often only received once the cartel failed - perhaps also a reflection of the lack of consequences for the individual decision makers. ${ }^{60}$ The UK and Ireland are two notable member states with criminal offences in place. However, Irish prosecutors have thus far only pursued local infringements (such as car dealers), none of which have resulted in custodial sentences. In the UK, there have only been three convictions to date in Marine Hoses, all of which came about as a result of a plea bargain previously reached with the DOJ, in which the defendants agreed to be repatriated on condition that they plead guilty to the UK offence. ${ }^{61}$

A significant obstacle in the UK is that a jury must be satisfied that the individual 'dishonestly' agreed to the cartel practices by the standards of reasonable and honest people, and that they knew what they were doing was dishonest by those standards. ${ }^{62}$ The pending trial of four British Airways executives could prove very significant if they successfully contend that their behaviour was not dishonest by those standards. Looking to the future, the fledgling UK cartel offence may be greatly assisted if employees confirm in

\footnotetext{
${ }^{57}$ GF Masoudi (US Department of Justice), 'Cartel Enforcement in the United States (and Beyond)' Speech delivered at The Cartel Conference, Budapest, February 2007.

${ }^{58}$ Kolasky (n 35).

59 A Stephan, 'An Empirical Assessment of the European Leniency Notice' (2008) Journal of Competition Law and Economics.

${ }^{60}$ Ibid.

${ }^{61}$ See Stephan (n 42); OFT Press Release 72/08, 'Three imprisoned in first OFT criminal prosecution for bid rigging' (11 June 2008).

${ }^{62} R$ v Ghosh [1982] 2 ALL ER 689.
} 
writing that they understand all cartel behaviour to be dishonest by the standards outlined above. Shareholders can play a key role in ensuring everything is done within the corporation to assist prosecutions by the competition authority in order to promote desistance.

\section{Concluding Remarks}

Cartel practices which amount to price fixing, market sharing, bid rigging and output restriction result in enormous corporate fines, even where they only involve a handful of employees. Internal compliance programmes are thought to protect firms, in particular by training employees in order to prevent future infringements, and by auditing their activities so that current ones might be detected. It is thought that the support of senior management is fundamental to a successful compliance programme. The need for effective compliance is heightened by leniency programmes which only provide immunity to the first firm to self-report an infringement. While the educational importance of compliance programmes in limiting unintentional breaches is beyond doubt, this paper argues that such programmes may be ineffective at preventing and uncovering deliberate cartel infringements. We know empirically from international cartels uncovered in the last ten years, that the individuals responsible typically know what they are doing is illegal, go to great lengths to avoid detection and are usually senior managers within the corporation. Moreover, EU and US competition authorities do not mitigate fines where compliance programmes are in place, even where the firm has disciplined those responsible.

A central problem is that it is the firm and not the individuals responsible who bear the risk of corporate fines. In Europe, these are imposed years after the conduct ceased, by which time the instigators may have retired or moved on. If there is a perception within the industry that collusion is acceptable or that the chances of detection are low, then compliance programmes may simply serve to highlight how low the stakes are in relation to the enormous illegal profits that might be realised through a cartel. Wilful cartelists' temptation to collude will only be heightened during the current economic crisis, especially within firms who continue to set unrealistic profit targets for their managers. It is argued that compliance training can only be effective if there is a threat of criminal sanctions against individuals responsible for cartels. The offer of immunity to the first individual (or employees of the first firm) is important in sparking a race between the individuals involved to avoid incarceration, and has been used to great effect in the US.

Imprisonment and other sanctions levied on individuals are not available on the European Community level or in many other jurisdictions around the world. In the UK, the OFT's prosecutions in Marine Hoses and Passenger Fuel Surcharges could potentially signal the complementing of civil corporate fines against international cartels on the Community Level, with a criminal procedure on the national level. There are a number of difficulties which must first be overcome; in particular, the Commission cannot give guarantees of immunity against criminal prosecution on the national level as part of its 
leniency notice. However, if compliance programmes are to communicate a credible threat to individual cartelists, a combination of imprisonment and immunity to the first whistle-blower will be essential. It is encouraging that the number of jurisdictions with criminal offences (albeit infrequently used) is increasing, with Australia and South Africa the latest to criminalise. ${ }^{63}$ If firms are to protect themselves from the enormous cartel fines now frequently imposed on both sides of the Atlantic, they must accept the severity of cartel behaviour and treat those involved accordingly. They must also do what they can to make criminal prosecutions easier, should their employees choose to indulge in collusive practices. Only this way might a significant level of desistance be achieved.

${ }^{63}$ For a discussion of the Australian experience of criminalisation, see: Caron Beaton-Wells, "Criminalising Cartels: Australia's Slow Conversion" (2008) 31(2) World Competition pp.205-233. 